International Journal of Social Science And Human Research

ISSN(print): 2644-0679, ISSN(online): 2644-0695

Volume 04 Issue 04 April 2021

DOI: 10.47191/ijsshr/v4-i4-38, Impact factor-5.586

Page No : 827-830

\title{
Processes of Modernization of Local Government in Uzbekistan
}

\author{
J.D. Akramov ${ }^{1}$, Kh.N. Tukhtaboev ${ }^{2}$ \\ ${ }^{1,2}$ Lecturer, National University of Uzbekistan
}

\begin{abstract}
The article discusses the process of modernization of local self-government in Uzbekistan during the years of independence. In this regard, the author draws a number of conclusions in the direction of attracting innovations to the industry.
\end{abstract}

KEYWORDS: public administration, executive power system, local government, modernization, innovation, optimization.

\section{INTRODUCTION}

Over the years of independence, the need to reform and improve the activities of local self-government, which is the lower level of executive power in the Republic of Uzbekistan, has become urgent problem. This is due to the fact that the executive committees of the Soviets of People's Deputies, which were introduced in the Republic of Uzbekistan on the model of the former Soviet Union and for a long time were the executive and governing body, did not meet contemporary requirements at all. They were under the strong influence of the party bodies and could not decide anything on their own. As can be seen, the above issues could not be solved under the domination of the command-and-control system. These, in turn, made the reform of the local government system a topical issue for the leadership of the Republic.

For a long time, local executive bodies were entrusted with important tasks of managing economic development, cultural and educational work, monitoring compliance with labor and consumption standards, providing various services to the population, protecting property, public order, and protecting natural resources. and the environment and other tasks [1. 53].These reasons necessitated the creation of a new system of local executive bodies. Such a body became the governors.

\section{THE MAIN FINDINGS AND RESULTS}

Of particular importance was the introduction of the regulation of the government (institute) in Uzbekistan in order to improve the activities of executive bodies, increase their potential, and more clearly define their rights and obligations. In order to restructure local executive bodies, improve their system and activities, for the first time in Uzbekistan, the post of mayor of Tashkent was established, and on December 29, 1991, he was elected by the people of Tashkent. On January 4, 1992, the Law "On reorganization of local authorities of the Republic of Uzbekistan" was adopted, establishing the post of governor as a body of local executive power in all regions of the country.

The adoption of the new Constitution of Uzbekistan on December 8, 1992 marked a new stage in the activities of local executive bodies. For the first time in the Republic of Uzbekistan, the division of local power into representative and executive power has been strengthened at the constitutional level (Article 102 of the Constitution). Executive bodies - governors - will be formed in regions, cities and districts. Unlike representative bodies, governors were also formed in the districts of the city.

On September 2, 1993, the Law "On Local Government" was adopted. It defines the main tasks of the Councils of People's Deputies and governors on the basis of the norms of Articles 102-103 of the Constitution. According to Article 1, the third paragraph, "the Council of People's Deputies and the governor implement the tasks of socio-economic development common to the region, district and city, local laws, resolutions of the Oliy Majlis, the President and the Cabinet of Ministers. ensures the implementation of documents, decisions of higher Kengashes of People's Deputies, governors, relations between public authorities and citizens' self-government bodies of the Republic of Uzbekistan, the involvement of the population in the management of regions, districts and cities [2]. Local representative bodies have a two-tier system. According to Article 99 of the Constitution, "Councils of People's Deputies headed by governors in regions, districts and cities (except for cities subordinate to the district) are representative bodies of power, which decide issues within their competence in the interests of the state and citizens." Thus, the system of authoritys of the Republic of Uzbekistan - a set of governors of regions (Tashkent city) and cities and districts was created. Article 103 of the Constitution enshrines the principle of monopoly, stating that "governors of regions, districts and cities shall exercise their powers on the basis of monopoly and shall be personally responsible for the decisions and activities of the bodies they govern." This rule not only emphasizes the importance of individual leadership in the work of governors, but also strengthens their personal responsibility. One of the main reasons for the appointment of the governor was to 


\section{Processes of Modernization of Local Government in Uzbekistan}

strengthen the relationship between the central and local executive bodies, the lower bodies to carry out the documents of the higher bodies without exception, to strengthen the control of the higher bodies over the activities of the lower bodies [3. 35].

Subsequent reforms in the system of local government in the country began in 2003. On the basis of the Law of the Republic of Uzbekistan dated April 24, 2003 No. 470-II "On amendments and additions to the Constitution of the Republic of Uzbekistan", amendments were made to Chapter XXI of the Constitution - Fundamentals of Local Government. In particular, the provisions on the management of the activities of local councils of people's deputies by local authorities were deleted from Article 101.

Pursuant to the Law of the Republic of Uzbekistan No. ZRU-89, adopted on April 11, 2007, the second part of Article 102 of the Constitution "governors of regions and khokims of Tashkent are appointed and dismissed by the President of the Republic of Uzbekistan and approved by the relevant Council of People's Deputies" the words "and approved by the relevant Council of People's Deputies" were deleted. Thus, the President of the Republic of Uzbekistan can now appoint and dismiss regional governors and the mayor of Tashkent without the approval of the Council of People's Deputies.

Subsequent reforms in the system of local executive power were announced on November 12, 2010 by the First President of the Republic of Uzbekistan Islam Karimov at the joint session of the Legislative Chamber and the Senate of the Oliy Majlis of the Republic of Uzbekistan "The concept of further deepening democratic reforms and development of civil society in our country “. In particular, the Law of the Republic of Uzbekistan No. ZRU-366 of April 16, 2014 amended Article 103 of the Constitution by adding the second part in the following wording: "Governors of regions, districts and cities submit reports to the relevant Council of People's Deputies on the most important and topical issues of socio-economic development of regions, districts and cities, on which the relevant decisions are made by the Council of People's Deputies" [4]. This, in turn, is a specific manifestation of the democratization of public administration. After all, the accountability of the head of the local executive power, ie the governor of the region, district or city to the Council of People's Deputies, belongs to the forms of interdependence of the branches of government and the principle of mutual restraint.

Currently, the main task of state and local governments is to form an effective system of local government capable of socio-economic development and political stability of local structures that can meet the needs of modern society in global states. Optimization of the local government system means the creation of a rational model of local government in our country in today's specific socio-political and economic conditions.

Local government optimization is a system of goal-oriented actions to increase the efficiency of the local government system using traditional and innovative methods of change in the social, political, economic spheres of local government structure development. A narrower interpretation of local government optimization means the formation of effective political and administrative relations between state and local authorities, reducing the role of the state in local government, improving the structure of local government, democratization of local self-government. Innovative technologies are an inevitable condition of the process of optimizing local governance.

It should be noted that the main legal document on the activities of local governments is the Law "On local government" adopted in 1993. There have been a number of changes in the state and local government system over the years. There is a need to revise this law in accordance with the requirements of today's and modern economy [5. 130].

It should be acknowledged that the reform of local authorities has failed to address a number of issues that hinder the effective functioning of local governments. In terms of interaction with public authorities, the issue is the formation of sustainable areas of local self-government, the problem of separation of powers between levels of government, the transfer of some state powers to local governments, the formation of their own financial and economic base and accountability to the local budget, the control of public authorities over local governments, the influence of informal institutions on the local level of government.

In addition, it is necessary to develop mechanisms that would allow the interests of local government to be transferred directly to the central level through the creation of a council office, consisting of representatives of local authorities.

The internal governance of local governments often needs serious adjustments based on the laws and regulations of governance, taking into account the political, economic and social changes taking place in our society. It is necessary to introduce and popularize a new culture of governance, based on which it is decided to recognize the person and his interests as the main value of the entire system of public administration in the country. It is necessary to solve the problem of providing local authorities with professional staff.

The field of interaction between society and government is the most important area that requires serious study and reform. The society should eliminate the guidelines of political culture based on unconditional obedience and form new worldview principles that shape the relationship between government and society on the basis of partnership, equality, openness and transparency. The relationship between local government and society requires serious democratization. On its basis, there should be a "guiding (receptive) model of governance" that guarantees the accountability of the system (the responsibility of local authorities) to the specific demands of citizens. Therefore, the main goal of local government should be focused on the interests of society and social significance.

Over the past few years, the introduction of innovations and their optimization in the activities of public administration at 


\section{Processes of Modernization of Local Government in Uzbekistan}

all levels in Uzbekistan has become a topical issue. Today, high-level government talks are underway to modernize the political system of Uzbekistan. Such tendencies in political governance cannot but affect the system of local self-government, which demonstrates the initial results of the reform process and the implementation of local reform. The transition to an innovative framework in the organization of the governance process and the exercise of its powers for local self-government is a more pressing issue than in regional or central authorities. This is a necessary step in the modernization of the entire political system and public administration of Uzbekistan.

From the very beginning of Mirziyoyev's presidency in the Republic of Uzbekistan, the first attempts were made to reform the structure of local government. In particular, the positions of First Deputy Governor for Economic Reforms and Entrepreneurship, as well as Deputy Governor for Youth Policy, Social Development and Spirituality were introduced in all regional, city and district authoritys [6. 50].This administrative-political reform is primarily aimed at increasing the efficiency of local governments.

The process of optimizing the activities of local authorities is primarily a political process. It cannot be a simple execution of a regional government decision, an element of an election campaign, or a PR move by the relevant services. Focusing on real optimization and increasing the efficiency of local government activities requires long and extensive work.

The principle of democracy is fundamental in modern social governance. Democracy is a system of organization of activities and relations that arises from the recognition of the people as the only source of power, the rule of law as a basic indicator of public life. Adherence to this principle implies the implementation of democracy in the management of society, in which all state and political regulation is aimed at the realization of the material and spiritual needs, interests and goals of citizens.

Another important principle in this regard is the departmental principle, which indicates the need to combine functional (network) territorial functions in city management. Unlike a transnational corporation in which such a combination is implemented, the consolidation of these functions in the city administration must be done on a parity basis and include the mandatory separation of special institutions - boards - to ensure the implementation of a single local policy to serve the interests of the entire city. The need to adhere to norms and living standards in local government brings social priorities as close as possible to economic goals, which are more pronounced in private enterprises.

In our opinion, the achievement of political, economic and organizational independence of local authorities should not be the main goal of the modern development of the political system of Uzbekistan. Local governments are part of the public administration system and are integrated into a common public administration system according to their nature and functional goals. Because they operate in the territory of Uzbekistan, it may not contradict the general state principles and directions of domestic and foreign policy. Second, they are specific agents of state action to implement public policy at the local level. In local governments, all spheres of public life must be developed on the basis of state policy, limited only by the scope of this local formation.

In addition, people living in regions, districts, cities and under the influence of local authorities are citizens of the Republic of Uzbekistan and are under state protection, which imposes certain responsibilities on local authorities and forces them to protect and comply with the rights and freedoms of citizens.

Thus, an important task of local authorities is to involve citizens in their activities, which ensures the legitimacy of local government and increases the level of public confidence in it. In general, effective interaction between local government and society is facilitated by addressing the following set of tasks:

- The activities of local authorities should be open, transparent and understandable to the population, providing access;

- It is necessary to reconsider the issues of local government management and adapt them to the specific needs of society;

- $\quad$ Radical restructuring of the bureaucratic system is required for the effective development of local government;

- At the local level, areas and problems that really need to be managed and addressed need to be constantly

monitored;

At the local government level, conventional communication methods should be gradually transformed into a communication process that is as close as possible to the population;

- It is necessary to introduce new methods of governance at the local level, for example, to further strengthen the system of medium-term and long-term planning at the legislative level, the "single window" system and services to the local population via the Internet;

- The adoption of legal documents at the local level should be based on the initiative and the interests of citizens; action; management culture needs to be changed, which means accepting citizens' initiatives and ideas as motivation for

- It is necessary to develop long-distance cooperation and international long-distance networks;

- It is necessary to develop the system of regional public self-government at the local level, to reform the process 


\section{Processes of Modernization of Local Government in Uzbekistan}

of public hearings, to hold more frequent local referendums and polls.

In our opinion, due to the specificity of the political culture of the population, the high level of distrust of local authorities, it is necessary to introduce innovations using "soft" methods. In other words, it is a matter of adapting innovations to the local conditions of development of all spheres of social life.

The practice of introducing innovative technologies in the activities of local authorities should be based on the principle that they meet the interests and needs of local communities, increase the participation of citizens in local self-government, focus on social harmony, justice, efficiency and transparency. The effectiveness of local government can be considered to be that the results of the activities of local authorities meet the requirements and expectations of the local community as much as possible. Thus, the main criterion for evaluating the activities of local authorities is not only economic growth, but also the satisfaction of the population, businesses and socio-political organizations with the activities of local authorities. "The most important thing is that as a result of these reforms we must create a prosperous and decent living environment for our people"[7].

\section{CONCLUSION}

In short, the legal consolidation and introduction of innovations in the activities of local authorities should be based on the principle of "transparency of the decision-making process at the local level." The necessary tools should be public discussion of decisions at the local level, ease of access to information about them, online broadcasting of meetings of state bodies and working meetings, the need for experts to evaluate the results of decisions, their monitoring, etc. The mandatory control system is of particular importance in ensuring the effectiveness of local government and local self-government. The rule that central government bodies work in coordination with local authorities in resolving issues of local importance is being implemented.

Such a control system must inevitably include elements of control by the central, local authorities, internal control and monitoring of their activities, and public control. The sphere of control should be determined in accordance with the principle of separation of powers, independence of local self-government and should be primarily aimed at protecting the interests and rights of citizens.

\section{REFERENCES}

1) Choriyorov U. Democratic rules of organization and activity of governing bodies. Towards a democratic state. Tashkent: 1993. - p.53.

2) Collection of Legislation of the Republic of Uzbekistan, 2004, No. 51, Article 514.

3) Husanov O. Independence and local government (legal, organizational issues and problems). Tashkent: "Sharq", 1996. p.35.

4) Collection of Legislation of the Republic of Uzbekistan, 2014, No. 16, Article 176.

5) Otaboev Sh. Territorial governance: legal framework, problems and solutions. // Society and governance. №4 (82), 2018. -p.130.

6) Mirziyoev Sh.M. Critical analysis, strict discipline and personal responsibility should be the daily rule of every leader's activity. Tashkent: "Uzbekistan”, 2017. -p. 50.

7) Address of the President of the Republic of Uzbekistan Shavkat Mirziyoyev to the Oliy Majlis of January 24, 2020/ https://president.uz/uz/lists/view/3324 